\title{
Poly-nuclear urban system, landscape identity and economic development: The Vega Baja of the Segura River (Alicante) case study
}

\author{
Clara García Mayor ${ }^{1}$, Gregorio Canales Martínez ${ }^{2}$ \\ ${ }^{1}$ Departamento de Edificación y Urbanismo. Universidad de Alicante. Spain \\ ${ }^{2}$ Departamento de Geografia Humana Universidad de Alicante. Spain \\ E-mail:magarma@ua.es,gregorio.canales@ua.es
}

\begin{abstract}
The geographical area of this study -the Vega Baja alluvial plainis characterized by its intensively irrigated agricultural pattern. It is one of the last remaining Huerta European landscapes identified in the Dobris Report and dates back to the ninth-century. Since the 1990s, the introduction of new land uses has modified the configuration patterns of otherwise stable traditional settlements. The exceptionally rapid pace of this process has had a significant impact on the landscape, the environment, and on how the local population relates to their surroundings. Moreover, in the last twenty-five years, the local economy has undergone restructuring, producing a mind-shift among local communities and resulting in a meaningful loss of crop production surface to make way for town-planning developments. The preservation of the Huerta's landscape identity requires a comprehensive and integrated reference framework to ensure sustainable development which is a goal advanced by this work. To this end, four key categories -Landscape, Agriculture, Habitat and Tourism- are defined and analyzed over three separate time periods that reflect the evolution of the territory. The aim of this paper is to provide an analytical territorial framework that can inform and guide future decision making -in the context of sustainable economic development- that should embrace a comprehensive approach to Huerta landscape identity values.
\end{abstract}

Keywords: Poly-nuclear urban system, landscape identity, Huerta landscape, Vega Baja, Segura River

\section{Introduction}

The territory that comprises the Vega Baja of the Segura River (Alicante province) has experienced a drastic change in terms of land occupancy and settlement growth patterns in the last twenty-five years evidenced by the introduction of new economic activities. Agricultural land use has been declining and in its place tourism related businesses have flourished. New emerging patterns of urban settlements, driven by changing economic factors have been highlighted. This process has significantly impacted the landscape and how the local population relates to their living environment. The Vega Baja plane of the Segura River developed from the expansion of its functional network systems -water canals (irrigation and drainage), routes (pathways), and enclaves (settlements)- which enabled the occupation and colonization of extensive areas of marshy land from the ninth century. The territorial organization of this study's area developed over the course of eleven centuries and remained relatively stable until after 1986, when agriculture lost its primacy and followed by an intense rural exodus (García-Mayor \& Canales Martínez, 2017). Consequently, over the course of the last twenty years specific changes in land management policies have 
been implemented. The local economy has undergone rapid restructuring along with a mind-shift among local communities, resulting in a trend away from agriculture to property developments. This trend is visibly evident in the meaningful loss of crop production surface. The Vega Baja is one of the last remaining Huerta European landscapes identified in the Dobris Report. Thereby, a more comprehensive and integrated approach is required to preserve the values inherent in Huerta landscape identity and local culture. This paper bridges the knowledge gap surrounding the Huerta by analyzing the categories -landscape; agriculture; habitat; and tourism- across three key time frames. The objective of this integrated approach is to understand the territorial processes from a chronological perspective which would facilitate better integration between the planning and managing of strategies for more sustainable economic development of the area in question.

\section{Methodology}

The methodology adopts an explanatory case study research (Yin, 2009) that explores cause-effect relationships between quantitative and qualitative holistic data. This approach highlights the coherence inherent to structural landscape features in different spatial scales and the consequences of changes which erode the main identity characteristics. Following the argument of Marc Antrop (2005), the changing perception of a place also influences the types of and the various aspects of landscape that are studied, protected and managed.

The Vega Baja of Segura River is a territory that has been widely studied by several authors and researchers from different perspectives: agrarian structure (Canales, 1993); changes in urban growth (Vera, 1984; Torres, 1995; Casado 1997; Martí \& Nolasco-Cirugeda, 2011); landscape identity (Ponce, 2011; Garcia-Mayor, 2017); tourist development (Navalón, 2003; Huete \& Mantecón, 2011; Canales \& López, 2012; Morote \& Hernández, 2016); real estate development (Burgos, 2011; Martínez, 2016). This study provides a compilation and analysis of the most relevant research results of the Huerta case study with complementary fieldwork that provides an updated and enhanced overview of how the territory's settlements have evolved. The study also considers the population's perception of the territory and focuses on two main processes: changes in space configuration promoted by new productive activities and addressed through four key aspects: landscape, agriculture, habitat and tourism; and the change in the community's mindset over the three defined time periods shown in Figure 1.

Up to 1965 this territory had a predominance of arable crops -up to four crops per year - following a ten-century tradition. From 1966 to 1994, a marked changeover occurred from the exclusive hegemony of arable crops to the introduction of irrigated mainly citrus tree orchards. After 1994, the area entered a new phase driven by the urban and territorial planning legislation of the Valencian Community. The political will to promote an economy based on urban development projects resulted in the fragmented but rapid process of urbanization of agricultural plots (Figure 1). The territorial transformation described in this case study has a direct repercussion on the way locals interact with their environment. This in turn influences the perception of the value of cultural assets such as the Huerta -largely driven by economic interests- and is reflected in the laws passed and policies implemented.

\section{Stages of the Territory's spatial organization}

Huerta landscape's character from inception to 1965 , reflected distinctive features of Vega Baja territorial configuration caused by secular human adaptation to the adverse environmental conditions existing in this area characterised by its aridity, periodic floods and relict swamp areas. The Huerta's longevity is crucial to understanding the significance of the changes that occurred post 1965, which have altered the traditional landscape model.

Up to 1965 the traditional agricultural Huerta landscape followed the same organizational and cultural patterns which enabled settlement and 


\begin{tabular}{|c|c|c|c|c|}
\hline Period & Landscape & Agriculture & Habitat & Tourism \\
\hline Until & $\begin{array}{l}\text { Predominance } \\
\text { of Arable } \\
\text { Crops }\end{array}$ & $\begin{array}{l}\text { Subsistence farming } \\
\text { - Direct land tenure } \\
\text { - Fragmentation of } \\
\text { land ownership }\end{array}$ & $\begin{array}{l}\text {-Rural population } \\
\text { adapted to Huerta } \\
\text { environment } \\
\text { - Linear hamlets } \\
\text {-Scattered dwellings }\end{array}$ & $\begin{array}{l}\text { - On coastal strip } \\
\text { - Recreational use of } \\
\text { rural environment } \\
\text { - Secondary } \\
\text { economic activity }\end{array}$ \\
\hline $\begin{array}{c}1966 \\
- \\
1994\end{array}$ & $\begin{array}{l}\text { Transition to } \\
\text { Irrigated tree } \\
\text { crops }\end{array}$ & $\begin{array}{l}\text { - Mechanised } \\
\text { commercial } \\
\text { exploitation } \\
\text { - Part-time farming } \\
\text { - High number of } \\
\text { small farms }\end{array}$ & $\begin{array}{l}\text {-Intensive rural } \\
\text { exodus } \\
\text { - Moderate urban } \\
\text { growths } \\
\text { - Unsuitability of } \\
\text { traditional house } \\
\text { typology }\end{array}$ & $\begin{array}{l}\text { - Mass tourism } \\
\text { begins } \\
\text { - Holiday apartment } \\
\text { main tourist model } \\
\text { - Isolated housing } \\
\text { estates }\end{array}$ \\
\hline Since & $\begin{array}{l}\text { Transformation } \\
\text { towards } \\
\text { fragmented } \\
\text { urbanised } \\
\text { agricultural } \\
\text { plots }\end{array}$ & $\begin{array}{l}\text { - Loss of agricultural } \\
\text { competitiveness } \\
\text { - No intergeneration } \\
\text { continuity } \\
\text { - Change of } \\
\text { entrepreneurial } \\
\text { mindset }\end{array}$ & $\begin{array}{l}\text { Urban legislation as } \\
\text { driving force for } \\
\text { changes } \\
\text { - New settlement } \\
\text { patterns } \\
\text {-Residential Tourism }\end{array}$ & $\begin{array}{l}\text { New inland } \\
\text { development areas } \\
\text { - Property } \\
\text { developments linked } \\
\text { to golf courses } \\
\text { - Revisiting Huerta's } \\
\text { environmental value }\end{array}$ \\
\hline
\end{tabular}

Figure 1. Vega Baja of the Segura River Huerta: chronological evolution of the four key categories.

agricultural production with the transformation of this marshy land. The colonization of this valley progressed in line with the development of the network of irrigation and drainage canals. This eliminated the health problems associated with large areas of still water. Progressively, over ten centuries, topography, geomorphology and flood risk were the factors responsible for defining and creating this specific agricultural landscape -the Huerta-. The development of this complex system involved the overlapping of four functional networks: water lines irrigation and drainage canals-; routes pathways-; settlements -small villages, linear hamlets, scattered dwellings-; agricultural production -plots and crops-.

The water network is the key element in the valley spatial configuration. This is a balanced network, designed with minimum slope, obtaining maximum use of minimum water resources. The Pathway network constitutes the second most important Huerta landscape structural feature. It is a dense mesh hierarchically organized. Apart from its evident function, which is the connectivity between settlements and the fields; the paths also provide access to the canals and the other components (e.g. canal locks) for water management control and for maintenance of the network. Water and pathway networks have influenced both the occupation and development of this valley as well as settlement territorial locations, patterns and shapes.

Settlement locations in this area have always been conditioned by the Segura River flooding episodes' level, as well as the preservation of the most productive agricultural land. The Poly-nuclear urban system in the Huerta territory is composed of the aforementioned settlement types -small villages, linear hamlets and scattered dwellings-. Small villages are located in three types of strategic areas: i) at the lower end of the mountain slopes, positioned between the irrigated Huerta plain and the dry crop areas; ii) in the middle of the plain on a slightly raised area caused by the accumulation of sediment; and, iii) below the $10 \mathrm{~m}$ isohypse from the 18th century during the final period of the Huerta expansion. The linear hamlets are the most characteristic form apart from the main settlements. Their origin was the agricultural labourer's sub-standard single-family dwelling that spontaneously occupied the narrow space between the trail passage width and the fertile agricultural plot, through the appropriation of the ground strip along traditional pathways. The dwellings formed an alignment, following the shaft pathway network, remaining only on one side of the trail and using the minimum surface to prioritise productive land. On some routes, 


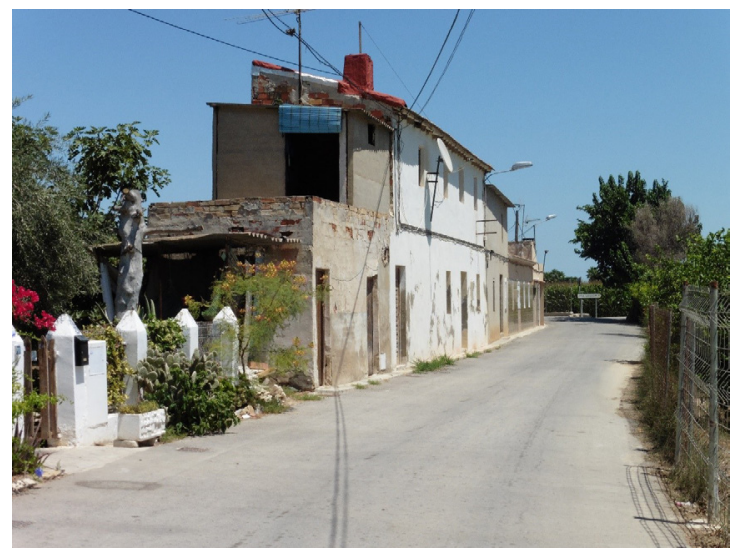

Figure 2. Typical linear hamlet. Pressure from tourist and residential demands: widening road network by covering the waterways.

the pathway was so narrow that part of the house extended over the water canal. Finally, scattered dwellings were typical farmhouses, situated in the core of smallholding agricultural areas.

The Huerta landscape transformed this alluvial plain, providing a greater visual and cultural homogeneity based on the agricultural practices and the settlement patterns and shapes as well as their spatial distribution throughout the Vega Baja area. The entire Vega Baja plain was a homogeneous landscape before 1965 , characterised by predominant shortcycle crops as well as scattered settlement distribution which generated peri-agricultural urban areas with an extensive visual scope. Both agriculture and habitat combined to create a landscape perception based on the dynamics of crop rotation and other local agricultural practices. The village of Orihuela was the main referral capital city for urban, administrative and commercial services.

During the 1970s, some reservoirs were built for water regulation near the edge of the valley to decrease the flood risk and provide a better water distribution throughout the year. This facilitated the progressive introduction of orchards -mainly lemon tree- which gradually replaced vegetable crops, providing a permanent green canopy, changing the image of the Huerta landscape.

The period between 1966 and 1994 is a kind of transitional model from the agricultural system to a new economic model,

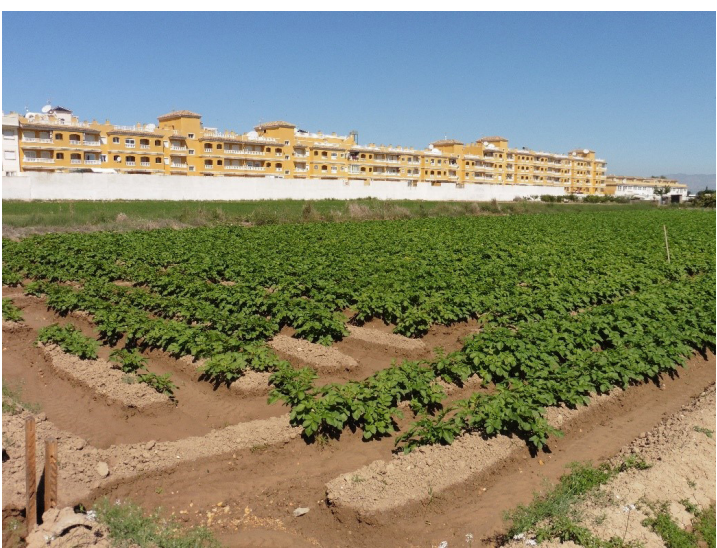

Figure 3. Urban expansion in the area between the urban tissue and the Huerta plots. Building typology reproducing typical coastal designs for tourists.

characterized by two main features: agriculture as an economic base; and new opportunities for property development and investment using profits from agricultural production. In this latter case, the local agricultural production evolved from a subsistence agricultural production to market driven production. The spread of citrus orchards during this stage had several consequences. From the landscape perspective, the Huerta panorama changes from a dynamic landscape with seasonal changes to a what we can labelled as a static landscape, fragmented by scattered orchards surrounding vegetable plots. Socially, there is a reduction in the demand for agricultural labour which resulted in a rural exodus of day-labourers that were replaced by specialized groups. Economically, the continuity of owner farming but with agriculture as a part time activity as well as changes in the commercialization of agricultural products, among others (Canales $\&$ Ponce, 2016).

The position of the city of Orihuela as the main urban center losses its hegemony when the small towns and villages scattered across the valley grow and extend their urban services and business offers. The residents of the consolidated linear hamlets remain but modernize and refurbish their clustered humble houses to improve comfort and habitability. For this purpose, the house's ground occupancy increases, resulting in a loss of the existing small courtyards between houses, where neighbours used to carry out some of the domestic duties, 
as well as some secondary farming tasks. Replacing the courtyards, a kind of continuous façade appears, hiding the visual links between fields and pathways, as well as removing the social space for resident interaction. This transformation causes the gradual emergence of abandoned farm houses and agricultural plots. There has been a progressive mindset change attracted by the new property market spurred on by the development of tourism nearby on the Mediterranean shores

From the mid-1960s, the Vega Baja coastal strip was a highly developed area with its emergence as a sun-and-beach tourism destination. This space was originally the main summer leisure destination for locals, who copied the Huerta linear hamlet model in front of the sea, and this configuration was an attractive place for foreigners which stimulated the development of a very dynamic property market. The capital invested -mainly from the profits of Huerta agriculture- was used to develop apartment blocks for renting, replacing the traditional beach detached-houses. Additionally, the building and construction material sector and complementary services related to interior design flourish. The opportunity for farmers to have better incomes in the real estate sector represented the greatest factor that changed the local mindset.

In the 1990s there are two milestones in the management of the territory which had a significant effect on the Vega Baja area. The first one was the finalization of the works of the Plan de Defensa contra Avenidas en la

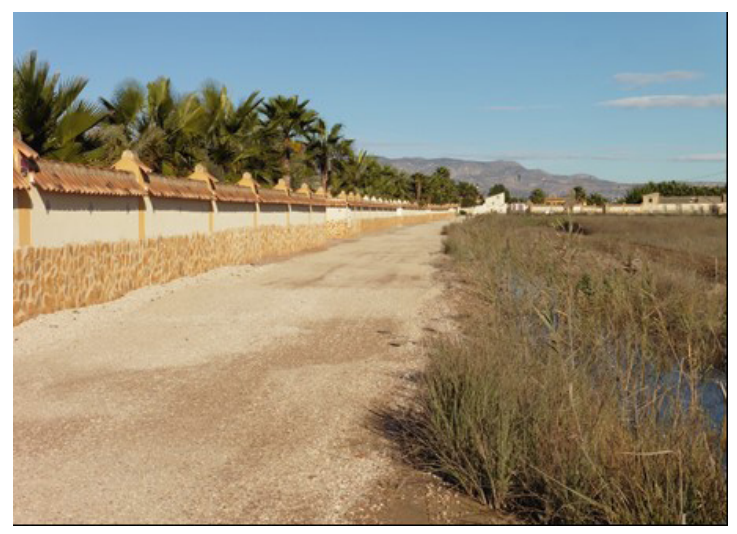

Figure 4. Abandoned Huerta plots in expectation of urban development in Almoradi.
Cuenca del Segura (Plan against the Segura River Flooding, drafted and implemented by the Segura River Water Authority). The modifications introduced to the river course and river bed reduced the risk of flood events and opened a new opportunity for the occupancy of the Huerta with residential developments in the pre-coastal strip. The second fact was the adoption of the Valencian Land Law in 1994. This new regulation provided flexibility and encouraged soil transformation for urban developments, which in turn gave investors a powerful tool which boosted the property market at the expense of the agricultural sector. As a consequence, in this stage there was a split from the traditional management of the land, and the characteristic balance between agriculture, housing and social context was disrupted.

The fieldwork undertaken in this area revealed the appearance of several low quality and fragmented areas which interfere with the perception of the traditional cultural space of the Huerta landscape. There is a process of transformation of the Huerta land into artificial surfaces due to the management of the territory in the last three decades. Only seven out of twenty-two main villages are originally located in the central area of the Vega Baja alluvial plain, but all of the twenty-two have developed their urban extensions occupying traditional Huerta plots towards the central part of this valley.

In addition to the aforementioned territorial occupancy, there have been developed some

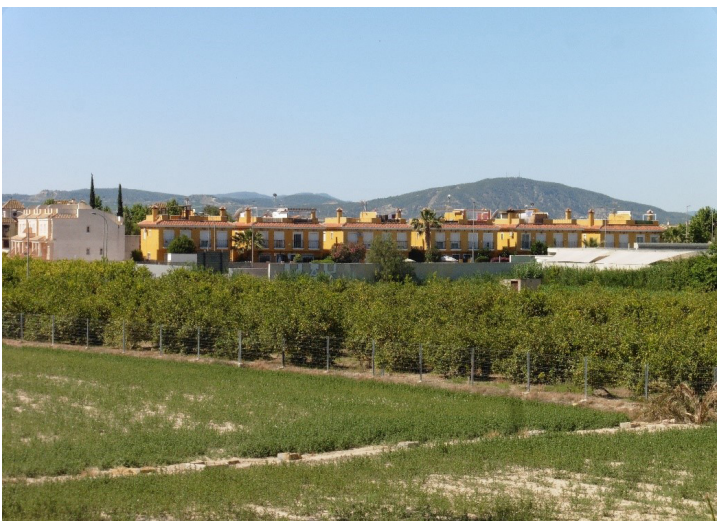

Figure 5. Landscape fragmentation: wall of a gated community comprising singlefamily dwellings 
major roads overlapped with the traditional Huerta path network, which implementation has promoted new areas for commercial strips, scattered industrial parks and residential developments. This situation has increased Huerta landscape fragmentation, as well as has produced loss of main landscape character features at different scales. From 2007 this tendency was slow down with the economic crisis and several significant urban developments, some associated to a golf course as an added attraction for property business, were led unfinished or abruptly paralyzed.

This territorial pattern has evolved from a balanced agricultural and town model, to a disaggregated and intrusive one. The coastal touristic model of residential developments has been copied inland as a successful real estate business, and foreign resident population registered represent more than the local inhabitants. As an example, the municipalities of San Fulgencio or Rojales, located at the lower end of the mountain slopes, positioned between the irrigated Huerta plain and the dry crop areas, have percentages of $60.3 \%$ and 70.5 $\%$ of foreign residents respectively. As well, we can also find municipalities such as Daya Vieja, located in the central part of the plain, surrounded by the traditional Huerta area, with similar percentages of foreign residents, $64.3 \%$ data compilation with information taken from the Spanish National Statistics Institute data (INE, 2011). All three examples have a different urban pattern and growth but are representative of the way new developments have been introduce in this territory in reference with the main town center: San Fulgencio and Rojales have scattered gated communities separated from the main urban nucleus; in contrast, the new developments in Daya Vieja study case are adjacent to the main village urban tissue. All these study cases represent a trend of change in this territory where radically changed Huerta landscape perception, in which urban grows has provoked a great environmental impact in a changing social context with a large foreign population.

\section{Discussions and conclusion}

The spatial organization of Huerta landscape at the Vega Baja of the Segura River in Alicante province has experimented important changes in relation with the loss of economical hegemony of the agriculture. The boosting of touristic activities as a profitable business has modify the way cities or new developments are planned and occupy the land, as well as a different way of interacting with the surrounding Huerta landscape. The consideration of the coastal strip as touristic attractiveness, together with good climate conditions, fostered this economical sector development which will extent from the coastline to inland. This way, the touristic residential designs spread into the adjacent historical Huerta landscape, where the green orchard trees canopy replace the blue Mediterranean Sea views, as environmental components of a desired nature. During the last decades tourism has lead the regional economic development in two different ways: directly with the consolidation of gathered residential developments in the coastline and also in connection with golf course areas; or indirectly in the inland municipal centers. As a result, the perception of the Vega Baja Huerta landscape has changed. This polynuclear and scattered territory has transformed the continuous Huerta's pattern landscape into a fragmented peri-urban agricultural space.

The Huerta landscape transformation has taken place in a short period-less than 15 years between 1994 to 2007- with a strong urban expansion, clearly impacted by the villages of Guardamar del Segura and Torrevieja, the latter being one of the forerunner cities in mass tourism and situated only thirteen kilometers distant from the Vega Baja valley. These developments were supported by locallygenerated capital -profits from agricultural production-, and driven by the Valencian urbanistic legislation. Susceptible of being understood as progress, these quick changes in the Vega Baja municipalities have had a negative impact over: settlements identity, the environment and Huerta landscape cultural identity. Place experience relates to a multisensory and cultural understanding, and it influences the local community will which 
in turn determines the community decision making. The Huerta of the Vega Baja is a prime example of this hypothesis.

\section{References}

Antrop, M. (2005) 'Why landscapes of the past are important for the future', Landscape and Urban Planning 70, 21-34.

Burgos Pérez, J. R. (2011) 'Guardamar del Segura: dunas con vistas de hormigón', in Urbanismo expansivo de la utopía a la realidad, XXII Congreso Geógrafos Españoles (Universidad de Alicante, Alicante) 91-102.

Canales Martínez, G. (1993) 'Modificaciones en las estructuras agrarias del Bajo Segura (1940-1990)', in Gil Olcina (ed.) Medio siglo de cambios agrarios en España (Instituto de Cultura Juan Gil-Albert, Alicante) 485-517.

Canales Martínez, G. and López Pomares, A. (2012) 'El desarrollo turístico de Orihuela y su incidencia en el poblamiento (19102010)', Cuadernos de Turismo 29, 109-135.

Canales Martínez, G. and Ponce Sánchez, M. D. (2016) Pareceres sobre la Huerta del Bajo Segura. El poder de la Identidad y la Cultura en la valoración del Paisaje (Universidad de Alicante, Alicante).

Casado Díaz, M. A. (1997) 'Crecimiento urbano y actividad promotora en Torrevieja, 19891995', Alquibla, Revista de investigación del Bajo Segura 3, 315-333.

García-Mayor, C. and Canales Martínez, G. (2015) La Huerta de Orihuela en el Bajo Segura. Elementos funcionales en la construcción del paisaje (Universidad de Alicante, Alicante).

García-Mayor, C. and Canales Martínez, G. (2017) 'Catral, de la huerta tradicional a la huerta urbanizada. La transformación del paisaje agrario en el Bajo Segura: del animus regandi al animus aedificandi', Cuadernos de Turismo 39, 191-213.

García Mayor, C. (2017) 'Invariantes en la evolución e identidad territorial del paisaje de Huerta tradicional de la Vega Baja del río Segura: 1929-2010', Boletín de la Asociación de Geógrafos Españoles 73, 369-388.
Huete, R. and Mantecón, A. (2011) 'Más allá del turismo: movilidad residencial europea y nuevos núcleos urbanos', Boletín de la Asociación de Geógrafos Españoles 56, 111-128.

INE (2011) Demografía y población (http:// www.ine.es) accessed April 2017.

Martí Ciriquián, P. and Nolasco-Cirugeda, A. (2011) 'La expansión urbanística reciente de la costa alicantina, una realidad constatable', in Urbanismo expansivo de la utopía a la realidad, XXII Congreso Geógrafos Españoles (Universidad de Alicante, Alicante) 367-378.

Martínez Guirao, J. E. (2016) Desarrollo inmobiliario y turismo. Un estudio sociológico sobre las consecuencias de la crisis en la Vega Baja del Segura (Universidad de Alicante, Alicante).

Morote Seguido, A. and Hernández Hernández, M. (2016) 'Población extranjera y turismo residencial en el litoral de Alicante (19602011): repercusiones territoriales', EURE 42, 55-76.

Navalón García, R. (2003) ‘Desarrollo turístico y mercado inmobiliario en la comarca del Bajo Segura (Alicante)', in López Trigal, L. et al. (coords.) La ciudad: nuevos procesos, nuevas respuestas (Universidad de León, León) 263-273.

Ponce Sánchez, M. D. (2011) 'Percepción de los procesos de urbanización y pérdida de los paisajes identitarios en la Vega del río Segura', in Urbanismo expansivo de la utopía a la realidad, XXII Congreso Geógrafos Españoles (Universidad de Alicante, Alicante) 555-566.

Torres Alfosea, F. (1995) Aplicación de un sistema de información geográfica al estudio de un modelo de desarrollo local: crecimiento urbano-turístico de Torrevieja (1956-1993) (Universidad de Alicante, Alicante).

Vera Rebollo, F. (1984) 'Mutaciones espaciales producidas por el turismo en el municipio de Torrevieja', Investigaciones geográficas 2, 115-138.

Yin, R. K. (2009) Case study research design and methods (Calif Sage Publications, Thousand Oaks). 